\title{
Use of Military Demolition Explosives in a Remediation Project
}

\author{
MICHAEL R. WALSH, CHARLES M. COLLINS, MICHAEL T. MEEKS, \\ ALVIN O. LEE, AND ERIC G. WAHLGREN
}

\begin{abstract}
Control of surface and subsurface water is a critical factor in the efficiency of remediation efforts at Eagle River Flats, an active impact range on Fort Richardson, Alaska, contaminated with particulate white phosphorus from artillery and mortar rounds. The Flats is an estuarine salt marsh bordered by bluffs with groundwater influx from the edges as well as periodic tidal and river inundation and rain events. The uneven topography and presence of numerous craters result in pooled surface water and high perched water levels, inhibiting remediation of the contaminant. Pumps are used to drain contaminated areas to enhance remediation, but ditching is required to enhance the operation of the pumps and to drain areas not conducive to pumping. Mechanical ditching is not feasible because of the softness of the ground and the presence of unexploded ordnance. To create pump sumps and ditches, military explosives have been used. This report details the sizes and configurations of these explosives (called demolitions), what has worked and what hasn't, and some of the lessons learned over the nine years of remedial activities at the Flats.
\end{abstract}

\section{SUBJECT TERMS}

Demolitions, Explosives, Military, Contamination, Eagle River Flats, White Phosphorus, Remediation, Superfund, Wetlands, Surface Water, Groundwater, Draining, Ditching.

Prepared for

U.S. ARMY ENVIRONMENTAL CENTER

Approved for public release; distribution is unlimited. 



\section{CONTENTS}

PREFACE $\ldots \ldots \ldots \ldots \ldots$
2
3

\section{ILLUSTRATIONS}

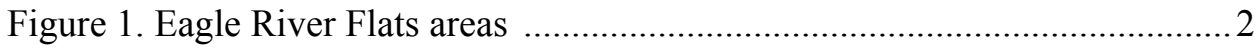

Figure 2. Pump system deployed at ERF ....................................................... 4

Figure 3. Location of blasted drainage ditches ................................................... 6

Figure 4. Preparation of shaped (foreground) and cratering charges .................. 11

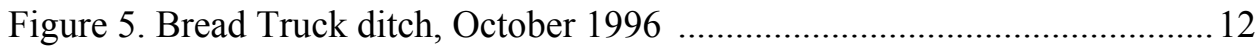

Figure 6. Drainage ditch at Pond 293 (cratering charges) ................................ 15

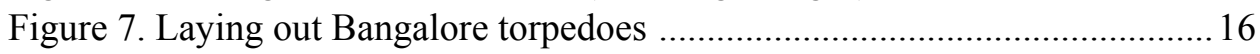

Figure 8. Drainage ditch at Pond 285 (Bangalores) ......................................... 17

Figure 9. Location of sumps for pond-draining missions ................................ 18

Figure 10. Blasting a sump drainage ditch with Bangalore torpedoes

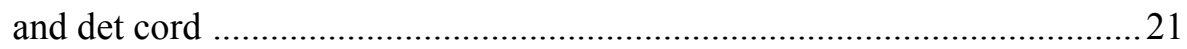

Figure 11. Field assembly of a five-strand det cord run ................................... 21

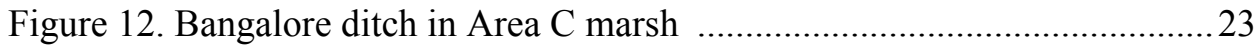

\section{TABLES}

Table 1. Predicted apparent scaled radius at optimum charge depth ................... 8

Table 2. Primary demolitions used at Eagle River Flats ..................................... 9

Table 3. Components of explosives in the primary demolitions .......................... 9

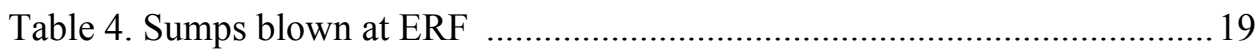

Table 5. Results of various ditching methods at ERF ........................................2 24 


\section{PREFACE}

This report was prepared by Michael R. Walsh, Mechanical Engineer, Engineering Resources Branch, and Charles M. Collins, Research Physical Scientist, Environmental Sciences Branch, Cold Regions Research and Engineering Laboratory (CRREL), U.S. Army Engineer Research and Development Center (ERDC). Assistance with this report was provided by LTC Michael T. Meeks (RET), LTC Alvin O. Lee, and MAJ Eric G. Wahlgren (RET). The manuscript was reviewed by Arthur B. Gelvin, Mechanical Engineering Technician, Engineering Resources Branch, CRREL, and Mark H. Kelliher, Resident Engineer, Alaska District, U.S. Army Corps of Engineers. David Cate of the Information Technology Laboratory, ERDC, was the editor.

This report is dedicated to the memory of Eric Wahlgren, a valuable contributor to the project and a friend to all who had the privilege to meet him.

Funding for this work was provided by the U.S. Army Environmental Center, Aberdeen Proving Ground, Maryland (Glen Boldt, Remedial Operations Manager), through the Alaska District, Pacific Ocean Division, U.S. Army Corps of Engineers (Joann Walls, Project Engineer), and the Environmental Resources Department, Directorate of Public Works, U.S. Army Alaska (William A. Gossweiler, Army Remedial Project Manager).

The Commander and Executive Director of ERDC is COL James R. Rowan, EN. The Director is Dr. James R. Houston. 


\title{
Use of Military Demolition Explosives in a Remediation Project
}

\author{
MICHAEL R. WALSH, CHARLES M. COLLINS, MICHAEL T. MEEKS, \\ ALVIN O. LEE, AND ERIC G. WAHLGREN
}

\section{INTRODUCTION}

Ditching and excavation projects using conventional construction and excavation equipment in military impact areas are very dangerous. The average misfire rates for fresh munitions are often around 3.5\%, with specific dud rates for certain types of munitions exceeding $20 \%$. These rates can climb when older munitions are used and the impact area is a wetland. In impact areas that have been used for many years, such as the Eagle River Flats Impact Range on Fort Richardson, Alaska, the amount of potential unexploded ordnance present can be quite large. Where excavation and ditching have been required in support of the environmental remediation efforts in Eagle River Flats (ERF), we have turned to Army Engineer troop units to conduct missions to create drainage ditches and sumps using military demolition materials. These missions have assisted the remediation efforts and lowered the exposure of personnel to unexploded ordnance while giving the troop units valuable training, allowing them to participate in a real-world project that assists in cleaning up the environment.

ERF has been used by the U.S. military since the 1940s as both an artillery range and an aerial impact range (Fig. 1). During its 60 years of use, over 100,000 rounds have been fired into this range. An estimated 3,000 pieces of unexploded ordnance (UXO) are present in or on the Flats. During the early 1980s, waterfowl die-offs in the Flats were reported and investigated by post and outside agencies (Tweten 1989). In 1990, the cause of the die-offs was determined to be the presence of white phosphorus (Racine et al. 1991, 1993). In 1993, feasibility studies were begun on methods to remediate the Flats. The dangers of operating on an active impact range are obvious, and methodologies were developed to reduce the risk to the investigators involved. The use of military demolitions for excavation and ditching operations in support of remediation activities is one of these methods. This report describes the military demolitions 
ordnance used to support operations at the Flats and covers the specific ways they are used to support the remediation program in the impact range.

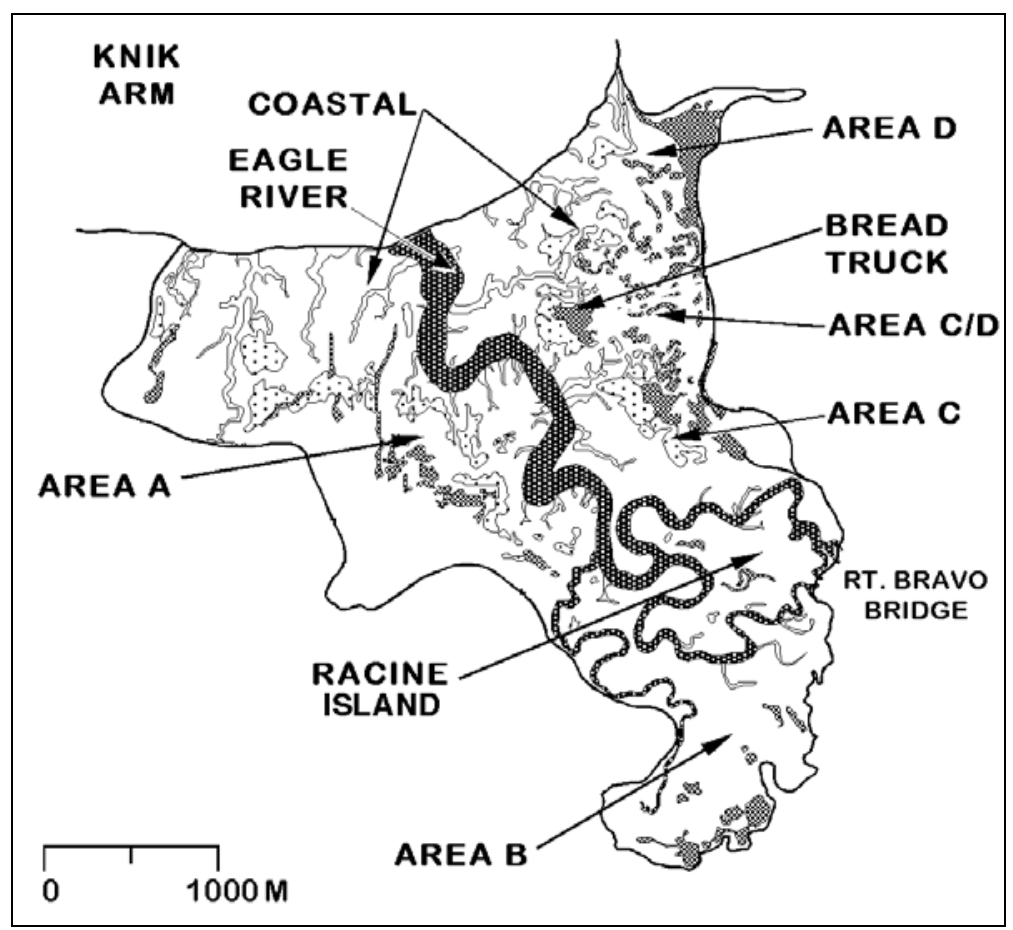

Figure 1. Eagle River Flats areas. 


\section{BACKGROUND}

White phosphorus $\left(\mathrm{P}_{4}\right)$ is the elemental form of phosphorus used in smoke munitions. It has a high vapor pressure and will readily sublimate when exposed to air. At room temperature, autoignition will occur and the material will burn violently. In the absence of air, $\mathrm{P}_{4}$ is quite stable. White phosphorus is normally stored under water for this reason. Cool, saturated soils with no open pore spaces are also very effective in preventing the sublimation and ignition of $\mathrm{P}_{4}$. At Eagle River Flats, the presence of ponded areas and saturated soils in a cool environment enables the retention of unburned residual particles of $\mathrm{P}_{4}$ from smoke munitions containing the material. Dabbling waterfowl, sieving the pond sediments for food items, may pick up these particles and ingest them while feeding. The ingested particles quickly poison the waterfowl, leading to their eventual death (Racine et al. 1992, Steele et al. 1997, Roebuck et al. 1998). To remediate the contaminant in Eagle River Flats, the sediment containing unreacted white phosphorus needs to be either physically removed and dried, covered, or treated in situ.

A study initiated in 1994 of the natural attenuation process of white phosphorus in sediment determined that if an area is drained and the soils allowed to desaturate and warm, white phosphorus particles will begin to sublimate and oxidize, leading to the eventual removal of the contaminant (Walsh et al. 1995, 1996). This in-situ treatment of white phosphorus contamination is the most environmentally benign remediation method, as it requires only the removal of the uncontaminated overlying water and drying of the sediments to treat the contaminant. Although effective over time in areas that are only intermittently wetted through tidal action or precipitation, conditions in permanently ponded areas are not conducive to this remediation mechanism. A more proactive method is required for these areas.

Two methods of active in-situ treatment involving pond draining were evaluated during the Treatability Study phase of the investigations at ERF started in 1995. The first method involved permanently draining contaminated ponds, thus exposing the contaminated bottom sediments and allowing them to dry. This is accomplished by excavating a drainage ditch between the pond and a nearby drainage gully or the river channel. The advantages of permanently draining a contaminated pond are the minimal operation and maintenance (O\&M) costs associated with this method following the initial excavation as well as the immediate removal of the drained portion of the contaminated pond as a potential source of waterfowl poisoning. However, reversing the drainage process and restoring the pond habitat in the future will be quite difficult because of the 
acceleration of erosion processes caused by the ditching. In addition, excavating a drainage ditch lowers the flooding threshold of the pond basin, allowing lower high tides to fill the basin, thus increasing the frequency of tidal flooding and increasing the time required for pond bottom sediments to undergo sufficient drying for the WP contamination to sublimate and oxidize in this and surrounding intermittently flooded areas. Because of the possibility of encountering unexploded ordnance, conventional excavation of drainage ditches using heavy equipment is not practical in Eagle River Flats.

The second pond treatment method involves temporary pond draining using a large-capacity pump. The pump removes the water from the ponded area, quickly removing the habitat from use by dabbling waterfowl and allowing the sediments to dry and the remediation process to initiate (Fig. 2). The pumping has to be repeated periodically, either as the basin starts to refill from surface water and groundwater inflow from the surrounding areas, after a rain event, or during one of the periodic flooding high tides. The greatest advantage of temporary pond draining is that it is easily reversible. After the pond bottom sediments dry sufficiently to sublimate and oxidize the white phosphorus, the pond environment can be restored by removing the pump and allowing the natural periodic flooding tides to refill the pond basin and restore the aquatic and emergent vegetation. An autonomous pumping system consisting of a float-mounted centrifugal pump and a separate float-mounted generator set (genset) connected by power and control cables was designed and built for testing purposes in 1995 (Collins et al. 1996, Walsh et al. 1999b, 2000). In the initial planning phase of the project, it became

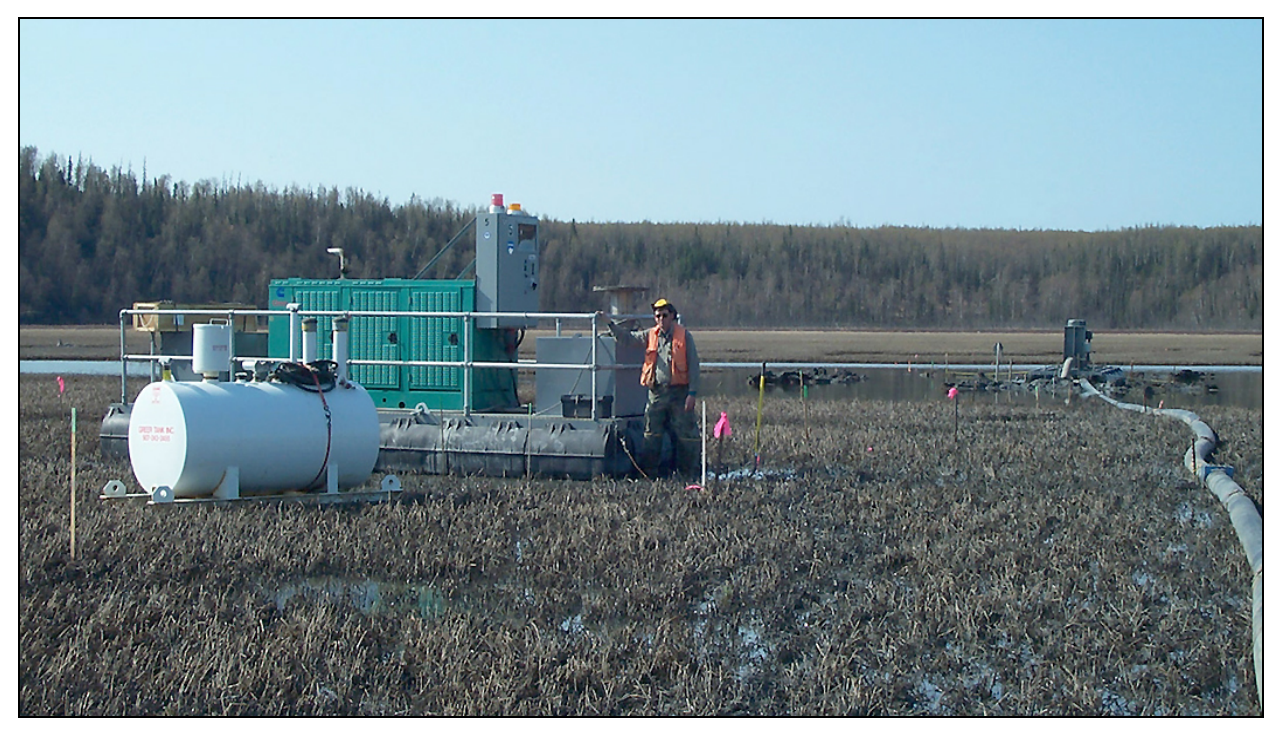

Figure 2. Pump system deployed at ERF. 
obvious from the relatively low relief of the shallow ponds that a sump in the middle of the pond is needed for the pumps to operate effectively. Without a sump, the pumps will cycle frequently as the water is repeatedly drained down around the pump. In addition, shallow drainage ditches are needed to connect scattered low points in the pond area to the sump. Ditches are also useful in treating adjacent contaminated ponds without the need of additional pump systems and sumps. All this needs to be accomplished with minimum human exposure to unexploded ordnance (UXO).

An analysis of the hazards and ground conditions for both remediation methods indicated that the best overall solution to the problem of safe excavation of material in the Flats is the use of demolition explosives. As Eagle River Flats is located on a military base and project funding is through the U.S. Army, military engineers were called upon to provide the required support. Military munitions and personnel are thus employed to support the effort to dewater contaminated areas in ERF as part of the ongoing remediation effort at the Flats. 


\section{MISSION DESCRIPTIONS AND SOLUTIONS}

The use of military demolition explosives in support of the Eagle River Flats project can be grouped according to the two remediation strategies. Permanent pond draining is a ditching process that results in the loss of the pond. It entails the formation of drainage ditches with large to medium cross sections. The support of the temporary pond-draining treatment is less intrusive. Sumps for pumps that temporarily drain the ponds are explosively formed, as are the interconnecting ditches with small to medium cross-sections used to drain the ponds to the sumps and control groundwater. These two missions are discussed separately below.

\section{Permanent Pond Draining}

Three drainage ditches have been explosively excavated to permanently drain contaminated ponds at ERF. The first, excavated in April 1996, drained Pond 109, a large, contaminated pond known as the Bread Truck Pond (Fig. 3). The second ditch, excavated in April 1997, drained a small, highly contaminated pond complex (Ponds 293 and 297) on Racine Island in the southern part of Eagle River Flats. The third ditch, excavated in June 2001, drained a previously treated small pond (Pond 285) on Racine Island where the capping treatment failed to prevent waterfowl from feeding in the contaminated sediments. Bread Truck Pond, the first pond permanently drained, was originally scheduled to be drained using a pump system. Budgetary constraints at that time prohibited the deployment of the system, and the pond was drained instead. Pond 293 is frequently

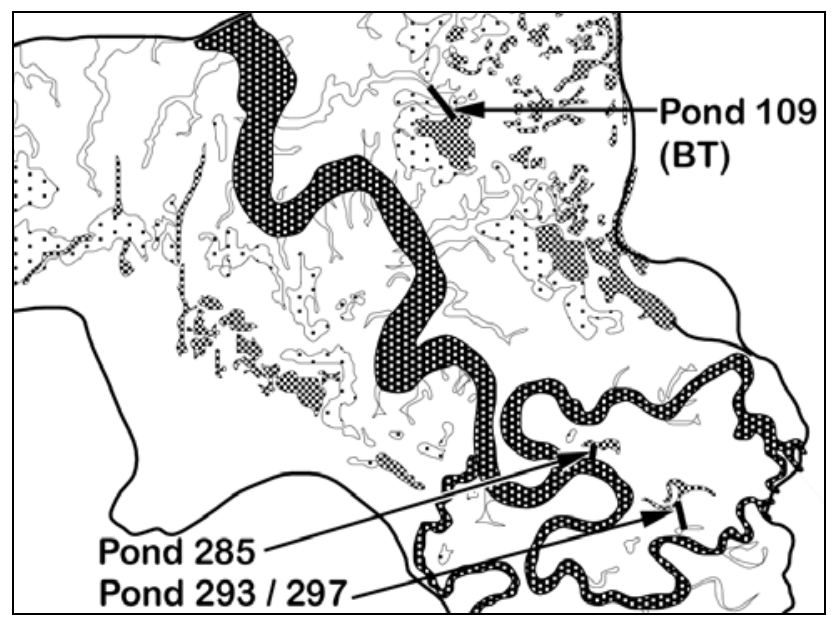

Figure 3. Location of blasted drainage ditches. 
flooded by high tides and was the location of high waterfowl mortality, so it was targeted for draining to remove it from use. Pond 285 is also subject to frequent flooding and was tested as highly contaminated after its initial treatment. Permanent drainage was determined to be the best option for breaking the contaminant pathway in this pond as well. The basic procedure for excavating a large-crosssection ditch, as outlined in the guidelines given in the Engineer Field Manual (U.S. Army 1992), uses a series of 18-kg (40-lb) cratering charges set off in a line to produce a series of overlapping craters. This procedure was used on the first two ditches. To produce the largest crater for the amount of explosive, the cratering charge needs to be placed at depth in a 30-cm-diameter borehole in the ground. The boreholes can be either mechanically augured or formed by standoff shaped charges. After the formation of the boreholes, cratering charges are placed in the holes and detonated, producing the final explosively excavated ditch. Because of the possibility of encountering UXOs in ERF, standoff shapedcharges were the only feasible choice to excavate the boreholes.

To facilitate the setting of the charges, reduce the risk due to UXOs, and enhance the effectiveness of the cratering charges, the first two explosive ditching missions were conducted in the spring while the ground remained frozen and the surface ice was minimal. A review of literature on the use of explosives to excavate craters in frozen ground gave some information on the expected size of a crater from a given charge size. The guidance given in FM5-34 and FM5-250 (U.S. Army 1987, 1992) on spacing of cratering charges is very conservative, placing charges close together and resulting in multiple overlapping craters. For normal soils, $18-\mathrm{kg}$ cratering charges placed every $1.5 \mathrm{~m}$ along the centerline of the ditch at 1.2-m depths will result in a ditch $6 \mathrm{~m}$ wide and $1.8 \mathrm{~m}$ deep.

A charge layout was developed to increase the spacing as much as practical yet still produce craters that will overlap to some degree, thus forming a connected ditch. Erosion from flooding and ebbing tidal water will erode out and widen any material left in the ditch. Increasing the spacing allowed the use of the minimum amount of explosives. This was a major consideration because of the desire to keep the blast as small as possible. Fort Richardson is adjacent to the community of Eagle River, and noise from range use is a factor in these operations.

Several authors have looked at the effects of explosions in ice and snow (Livingston 1960, Mellor 1965), in frozen ground (Livingston 1956,1959, Mellor and Sellmann 1970), and in and under floating ice sheets (Mellor 1982, 1986a, $1986 \mathrm{~b})$. The traditional analysis for determining the apparent scaled radius $\left(R_{\mathrm{a}}\right)$ and scaled depth $\left(D_{\mathrm{a}}\right)$ of craters formed by explosions uses cube root scaling (Mellor 1986a) to remove the effect of charge size (all linear dimensions are divided by the cube root of charge mass), allowing comparisons of craters 
formed by explosive charges of various sizes. For explosions at the optimum charge depth, the predictions in Table 1 can be made for the size of craters formed in moist clayey soil, frozen silt, and ice using the equations presented in Mellor (1986a, 1989).

Table 1. Predicted apparent scaled radius at optimum charge depth.

\begin{tabular}{|lccc|}
\hline & Moist clayey soil ${ }^{1}$ & Frozen silt $^{1}$ & Ice $^{2}$ \\
\hline$R_{\mathrm{a}}$ & $0.9 \mathrm{~m} / \mathrm{kg}^{1 / 3}$ & $0.9-1.1 \mathrm{~m} / \mathrm{kg}^{1 / 3}$ & $0.71 \mathrm{~m} / \mathrm{kg}^{1 / 3}$ \\
Opt. Depth & $0.5 \mathrm{~m} / \mathrm{kg}^{1 / 3}$ & $0.7-0.8 \mathrm{~m} / \mathrm{kg}^{1 / 3}$ & - \\
\hline
\end{tabular}

${ }^{*}$ Radius and depths of craters in $\mathrm{m}$.

${ }^{1}$ Mellor (1989)

${ }^{2}$ Mellor (1986a)

Both 6.8-kg (M2A4) and 18.1-kg (M3A1) shaped demolition charges are available for explosively excavating boreholes for the cratering charges. Smith (1982) showed that the $6.8-\mathrm{kg}$ shaped charge did not consistently give a wide enough borehole in frozen sediment to enable placement of the 20-cm-diameter cratering charge. Because of this we used the larger M3A1 18-kg shaped charge for the borehole excavations. The M3A1 shaped charge contains a Composition A3 booster and a 13.4-kg (29.5-lb) main charge of Composition B (U.S. Army 1998). Specific compositions can be found for this and other demolition materials in Tables 2 and 3.

The 18.1-kg cratering charge used to excavate the large ditches is a watertight, cylindrical metal container with approximately $13.6 \mathrm{~kg}$ of AN-base explosive with a TNT explosive booster (U.S. Army 1998). Using the equations of Table 1, a single cratering charge placed at the optimum charge depth of $1.3 \mathrm{~m}$ in moist clayey soil should produce a crater with an apparent radius of $2.4 \mathrm{~m}$, or an apparent diameter of $4.8 \mathrm{~m}$. In frozen silt, the same size charge placed at the optimum charge depth of $1.85 \mathrm{~m}$ should produce a crater with an apparent radius of $2.6 \mathrm{~m}$, or an apparent diameter of $5.2 \mathrm{~m}$. Based on these numbers we decided to place the cratering charges at $5-\mathrm{m}$ intervals along the planned line of the first ditch excavated in 1996. This spacing was decreased to $3.5 \mathrm{~m}$ for the ditch excavated in 1997.

\section{Excavation}

Pond 109 (Bread Truck Pond) is an isolated pond located east of Eagle River. Its name is derived from a target vehicle located adjacent to the pond. The Bread Truck (BT) Pond consists of an inner, permanently flooded pond with an area of $33,000 \mathrm{~m}^{2}$ (3.3 ha). An outer, intermittently flooded pond area of 5.4 ha 
Table 2. Primary demolitions used at Eagle River Flats.

\begin{tabular}{|c|c|c|c|c|}
\hline Type & Item & DODIC & Component & Composition \\
\hline \multirow[t]{2}{*}{ Block charge } & M5A1 $(1.03 \mathrm{~kg})$ & M038 & Explosive & Comp C4 (91\%) \\
\hline & & & & Plasticizers (9\%) \\
\hline \multirow[t]{2}{*}{ Cratering charge (old) } & $40 \mathrm{lb}(18.14 \mathrm{~kg})$ & M039 & Main Charge & AN $(13.6 \mathrm{~kg}-75 \%)$ \\
\hline & & & Booster & TNT $(4.5 \mathrm{~kg}-25 \%)$ \\
\hline \multirow[t]{2}{*}{ Cratering charge (newer) } & $40 \mathrm{lb}(18.14 \mathrm{~kg})$ & M309 & Main Charge & Comp H6 (18.1 kg - 98.5\%) \\
\hline & & & Booster & Comp A5 (0.2 kg - 1.5\%) \\
\hline \multirow[t]{2}{*}{ Shaped charge } & M3A1 (18.14 kg) & M421 & Main Charge & Comp B (13.4 kg - 100\%): \\
\hline & & & Booster & Comp A3 (0.05 kg-100\%) \\
\hline \multirow[t]{2}{*}{ Bangalore torpedo } & M1A2 (Kit-96 kg) & M028 & Main Charge & Comp B4 (4.76 kg - 100\%) \\
\hline & & & Booster & Comp A3 (046 kg - 100\%) \\
\hline Demolition accessory & Detonation Cord & M456 & Core Charge & PETN $(9.51 \mathrm{~kg} / \mathrm{km})$ \\
\hline
\end{tabular}

Table 3. Components of explosives in the primary demolitions.

\begin{tabular}{|lllc|}
\hline \multicolumn{1}{c}{ Explosive } & Abbreviation & Component & Percent \\
\hline Pentaerythrite tetranitrate & PETN & - & - \\
Cyclotrimethlenetrinitrate & RDX & - & - \\
Ammonium nitrate & AN & - & - \\
Trinitrotoluene & TNT & - & - \\
Composition A3 & Comp A3 & RDX & 91 \\
& & Wax & 9 \\
Composition A5 & Comp A5 & RDX (Type II) & 98.5 \\
& & Stearic acid & 1.5 \\
Composition B & Comp B & RDX & 60 \\
& & TNT & 40 \\
Composition B4 & Comp B4 & RDX & 60 \\
& & TNT & 39.5 \\
& & Calcium silicate & 0.5 \\
Composition C4 & C4 & RDX & 91 \\
& & Plasticizers & 9 \\
Composition H6 & H6 & RDX & 47 \\
& & Aluminum/oxygen & 30 \\
& & Wax / lecithin & 22 \\
\hline
\end{tabular}


surrounds the permanent pond, mainly on the west and south. Additional adjacent and connected intermittently flooded ponds on the north total another $1.0 \mathrm{ha}$. The pond area is surrounded on three sides by higher, vegetated mudflats. On the fourth side, to the east, the pond is bounded by a sedge and bulrush marsh complex in the $\mathrm{C} / \mathrm{D}$ area (Fig. 1). The elevation on this side of the Bread Truck Pond is lower than the other three sides, allowing some flow between Bread Truck Pond and the $\mathrm{C} / \mathrm{D}$ area at certain water levels. To the east of the $\mathrm{C} / \mathrm{D}$ area is an upland bluff marking the eastern boundary of Eagle River Flats.

Distributary channels or gullies leading to Eagle River are located on the south and north sides of BT pond. These allow tidal inflow into the pond during flooding high tides and provide drainageways for the area during the tidal ebb. The gullies were undergoing headwall erosion and were projected to eventually intercept and permanently drain Bread Truck Pond. In 1993 and 1994, the gully just northwest of Bread Truck Pond exhibited net headwall recession rates of up to $3.5 \mathrm{~m}$ per year (Lawson et al. 1994, 1995). Erosion increased dramatically during 1995, with headward erosion of $15 \mathrm{~m}$ or more (Lawson et al. 1996). It was predicted that if such rates continued, erosion would cause the pond to drain naturally within 2 to 5 years, rather than the 10 to 15 years predicted previously.

The BT pond basin is subject to periodic refilling under certain flooding high tide conditions. How often the pond is flooded and refilled during the summer depends on the maximum height of the monthly series of peak high tides. Some years will have only one or two series of flooding high tides during the summer. Other years, such as 1996, had a flooding series of high tides every month of the summer. Prior to the excavation of the drainage ditch, monthly peak high tides above about $31 \mathrm{ft}$ Anchorage tidal datum (or about $4.79 \mathrm{~m} \mathrm{MSL}$ ) would spill over a threshold into the pond basin from the nearby distributary gully, refilling the pond basin. Depending on the height of the flooding high tide, the water would fill the intermittently flooded pond areas up to a water surface elevation of about $4.95 \mathrm{~m}$ MSL. The water level in the pond then slowly drops as the floodwater flows out of the pond through the distributary channels. Additional drops in the water level below the threshold elevation occurred as evaporation reduced the amount of water in the pond.

The Bread Truck ditch was excavated in two stages (Fig. 4). The first stage used seventeen 18-kg shaped charges to explosively form boreholes into the sediment. The charges were spaced every $5 \mathrm{~m}$ along the centerline of the planned ditch. Type $1 \mathrm{M} 45$ line main detonation cord $(29.5 \mathrm{~g} / \mathrm{m}, 6.4 \mathrm{lb} / 1000 \mathrm{ft})$ connected all seventeen shaped charges together. A dual detonating firing system consisting of two fuse igniters, two lengths of time fuse cut to 7-minute lengths, and two blasting caps was used. When detonated, the shaped charge produces a plasma jet that will punch a $30-\mathrm{cm}$-diameter hole straight down into the ground. The total 


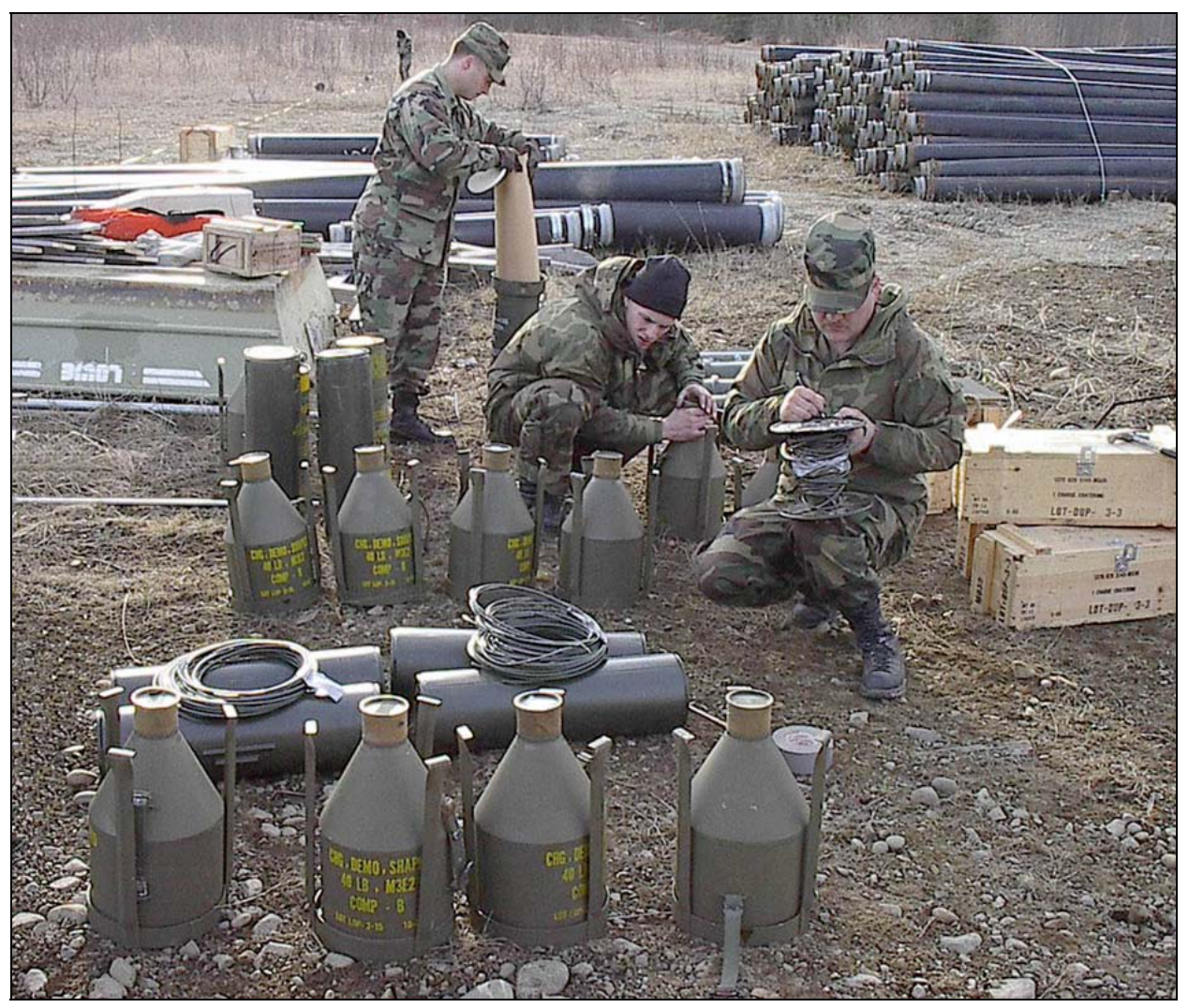

Figure 4. Preparation of shaped (foreground) and cratering charges.

amount of explosives detonated in this first explosion was approximately $320 \mathrm{~kg}$ (700 lb). Following a sweep of the area for UXOs, the second stage of the explosive excavation was set up. An 18-kg cratering charge was placed in each of the boreholes created by the shaped charges. The charges were wired together in a similar manner to the shaped charges. One or more sandbags were placed in most of the boreholes on top of the cratering charges. The number and way the sandbags were placed varied from hole to hole, depending on the soldier who did the placement. Since all the boreholes were filled with water from the pond, it was difficult to determine how effective the sandbags were in tamping the underlying charge.

The explosion of the cratering charges produced a series of craters forming a nearly continuous ditch $90 \mathrm{~m}$ long. Craters were up to $2 \mathrm{~m}$ deep and varied from 3.3 to over $6 \mathrm{~m}$ in diameter. The mean crater diameter was $4.92 \mathrm{~m}$. The smallestdiameter craters were within the slightly higher vegetated mudflat area near the northern end of the ditch and in the pond sediments at the southern end. The ground at the northern end was more deeply frozen, and the explosive charges 
may not have been as efficient in removing material. It is unclear why the craters at the southern end were smaller than predicted. Differences in crater diameter were likely due to differences in the effectiveness of tamping. Between one and three sand bags were placed in each borehole above the cratering charge, and almost all holes were filled with meltwater. The smaller-than-expected size of several of the craters caused some craters not to overlap. This created several blockages that prevented any initial flow through the ditch. Following the spring thawing of the pond ice and the surrounding seasonally frozen ground, a series of flooding high tides in late May eroded the blockages and initiated draining of the pond on 19 May 1996. Accelerated headwall erosion was evident by October of that year (Fig. 5).

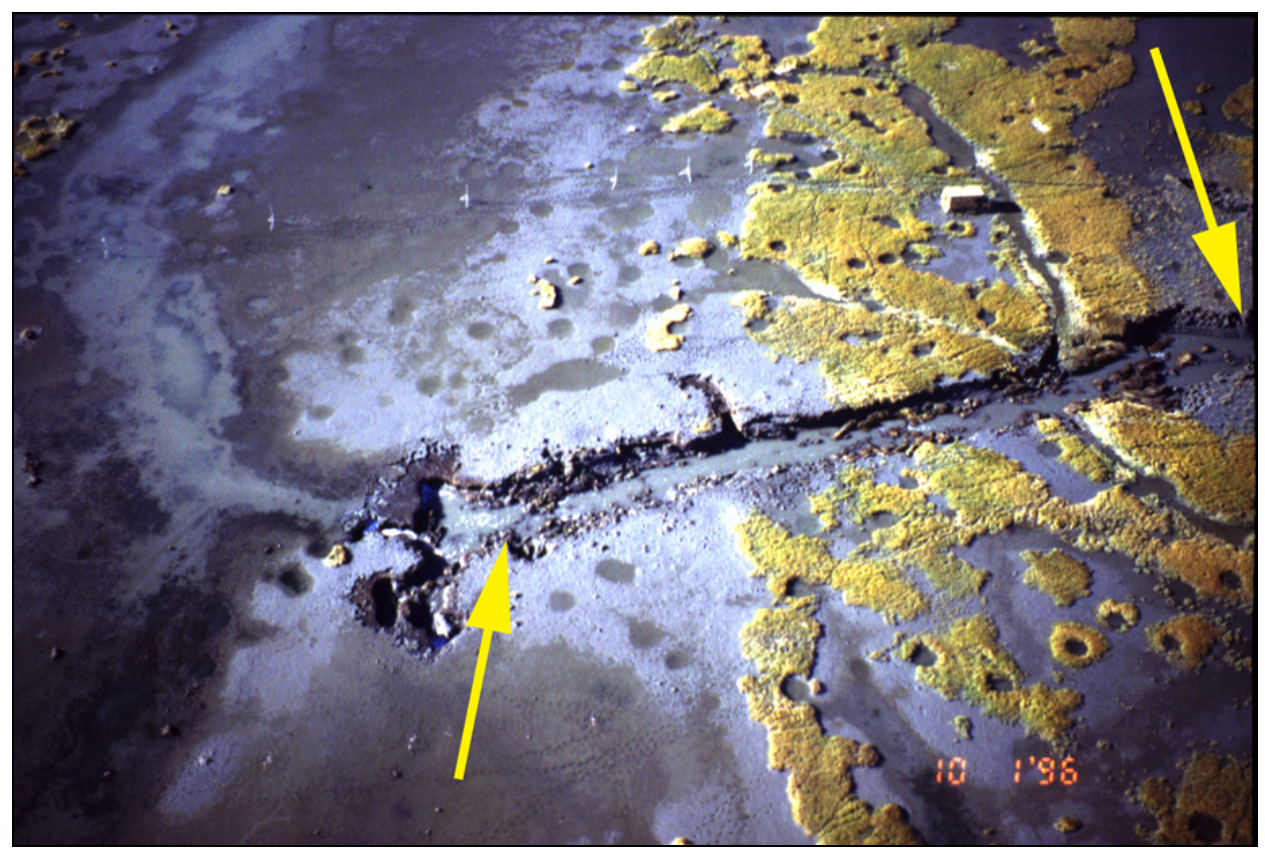

Figure 5. Bread Truck ditch, October 1996. Arrows point to the ends of the blasted ditch. Headwall erosion is evident to the left of the left arrow.

\section{Excavation}

Pond 293 is an isolated pond located within the south-central portion of Racine Island in the southern half of Eagle River Flats (Fig. 3). Racine Island is formed by the bifurcation of Eagle River just upstream of the Route Bravo Bridge. The right channel flows north and then west, while the left channel flows northwest and then north to rejoin the right channel, forming a 54-ha island. Pond 293 is a long narrow S-shaped pond that appears to be part of a former meander 
channel. The pond area is 1.0 ha. Prior to drainage, normal water depths in the pond ranged up to $50 \mathrm{~cm}$. The pond is surrounded by 6.4 ha of sedge marsh with standing water and bulrush up to $40 \mathrm{~cm}$ tall. Within the sedge marsh are scattered, small open-water ponds. This low area of pond and sedge marsh is in turn surrounded by a higher-elevation vegetated mudflat area of Ramenski sedge meadow (Racine et al. 1993). This Ramenski sedge meadow consists of finegrained (mostly clay with some silt) cohesive soil with sparse to dense low-sedge vegetation.

Tidal distributary gullies leading to Eagle River are located on both the north and south sides of Pond 293. These allow tidal inflow into the interior of Racine Island and the pond during flooding high tides and provide drainageways for the area during the tidal ebb. Neither gully had major headward erosion during the early- and mid-1990s, unlike other gullies in ERF (Lawson et al. 1995, 1996). The nearest gully to the pond, the gully to the south, is approximately $120 \mathrm{~m}$ due south of the deepest part of the pond located in the center of the S. The left channel of the river comes to within $90 \mathrm{~m}$ of the western end of Pond 293. However, the pond is shallow at this end, and the sedge meadow between the river and the pond is higher here than anywhere else on the island. This made it a less attractive route for a drainage ditch than the longer route from the center of the pond to the gully to the south.

The Racine Island pond basin and associated sedge marsh are subject to periodic refilling under flooding high-tide conditions. How often the pond is flooded and refilled during the summer depends on the maximum height of the monthly series of peak high tides and the stage of the river at the time of the tide. Prior to the excavation of the drainage ditch, the maximum water level in the pond when the pond basin was full was about $4.79 \mathrm{~m}$ MSL. This was the threshold elevation controlling water flowing in and out of the pond system. High tides above this level would flood and fill the pond basin. Depending on the height of the flooding high tide, the water would also fill the surrounding sedge marsh area up to a water surface elevation of about $4.95 \mathrm{~m}$. The water level in the pond and surrounding marsh would then slowly drop as water flowed out of the pond through the distributary channels. Additional drops in the water level below the threshold elevation occurred as evaporation reduced the amount of water in the pond.

Prior to the excavation of the ditch to Pond 293, we reviewed the results of the previous spring's operation. One of the lessons learned from that operation was that the charge spacing used $(5 \mathrm{~m})$ was slightly too long, resulting in some craters not overlapping. This produced narrow berms or barriers across the newly excavated ditch that did not allow flow out of the ditch until a flooding tide later in the spring eroded out the berm. The other lesson was that the cratering charges 
were not fully tamped, despite the holes being filled with water, resulting in part of the explosive force going upward instead of laterally, reducing the excavation efficiency of the charge. This resulted in several craters not being excavated to the expected diameter, again resulting in several narrow berms or barriers across the ditch.

On 21 April the area of the planned ditch was inspected and cleared by two UXO technicians. A right-of-way for the ditch, $5 \mathrm{~m}$ to either side of the centerline, was marked and cleared. Along the centerline of the ditch the planned location for each of the charges was marked at 3.5-m intervals. Two additional charge locations were marked at either end to ensure that the ends of the ditch were opened by the explosives. The southern endpoint of the ditch was at the edge of the gully system, south of the pond. The northern endpoint was within the target pond, $120 \mathrm{~m}$ away.

The ditch was excavated in three separate blasting operations, the first two to blast the boreholes and the third to excavate the ditch. Since the shaped charges are placed above the ground surface, they create a very loud, sharp noise and a considerable shock wave when they are detonated. The boreholes were therefore blasted in two stages, using twenty $18-\mathrm{kg}$ shaped charges each time. The charges were spaced at the previously marked locations along the centerline of the planned ditch, with the boreholes for the south half of the planned ditch being excavated in the first blast and the boreholes for the north half of the planned ditch being excavated in the second blast. The total amount of explosives detonated in each explosion was approximately $320 \mathrm{~kg}$. The UXO technicians inspected the area for any possible newly exposed UXOs after each detonation.

In each of the 30-cm-diameter boreholes created by the shaped charges, the soldiers placed an 18-kg cratering charge. The charges were wired together as detailed above for the 1996 mission. Each of the cratering charges was tamped or stemmed with four to five sandbags. The total amount of explosives detonated in this shot was approximately $750 \mathrm{~kg}$.

The detonation of all forty cratering charges produced a large explosion that threw material several hundred meters into the air. The explosion formed a nearly straight $120-\mathrm{m}$-long ditch, $2 \mathrm{~m}$ deep and $4.7-5 \mathrm{~m}$ wide, leading from the pond to the gully (Fig. 6). The problems encountered the previous year with the Pond 109 ditch with various sizes of craters and with some craters not overlapping were completely avoided. The closer spacing of cratering charges and the tamping of the boreholes containing the cratering charges with sandbags produced a more constrained explosion and a more consistent lateral excavation of ground material. Immediately following the blast, water started flowing into the newly excavated ditch from Pond 293. The first crater at the north end of the ditch was a 


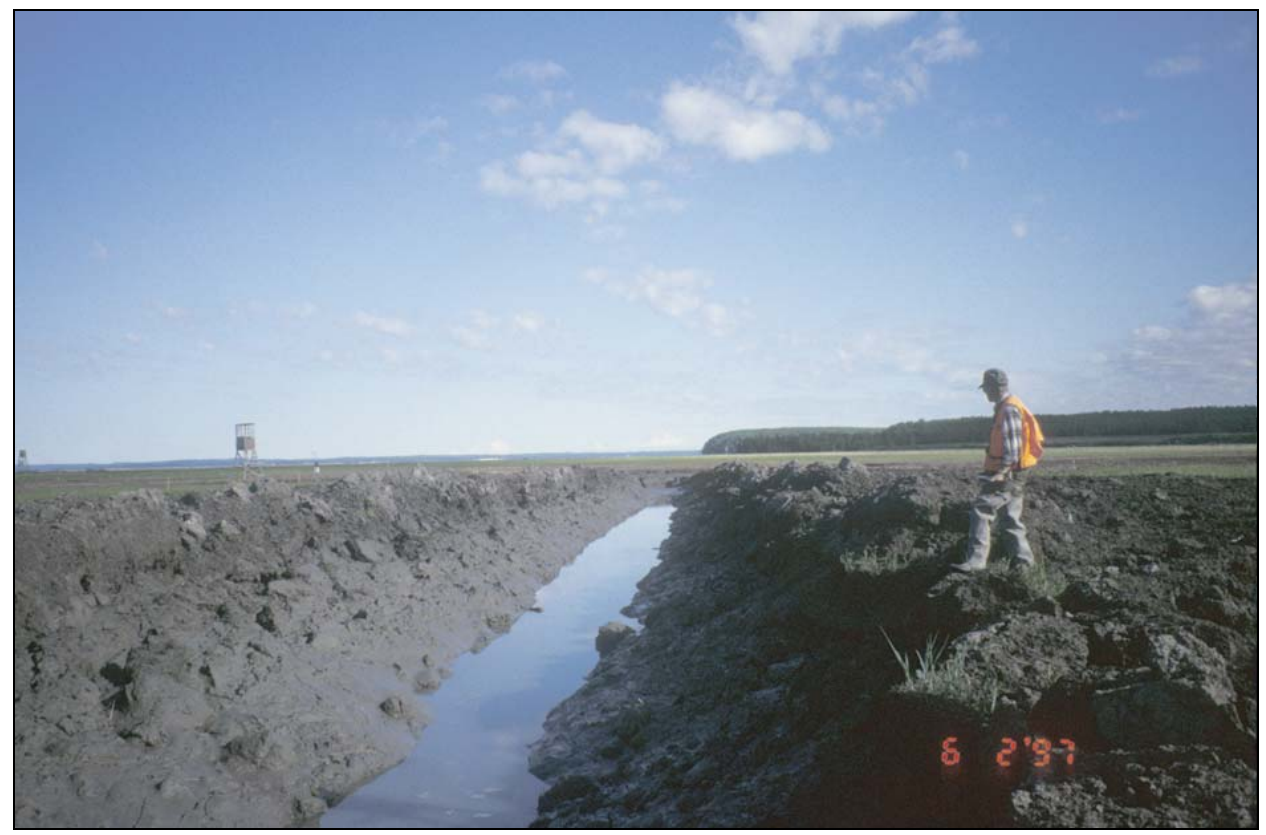

Figure 6. Drainage ditch at Pond 293 (cratering charges).

meter and a half deeper than the pond where it was located, resulting in a cascade of water down into the crater. Water continued to flow into and fill the ditch for about twenty minutes. After the ditch filled with water, it began to erode the berm thrown up around the last crater at the end of the ditch and flow out of the south end of ditch into the ice-filled gully and hence into the river. Water continued to flow out of Pond 293 and the surrounding sedge marsh for several weeks until the area drained.

\section{Excavation}

Evaluation of the ditch extension in the years following the draining of Pond 109 indicated that the loss of this permanent pond through accelerated gully headwall erosion is inevitable. This effectively removes this contaminated area from waterfowl usage but also excludes the option of easily restoring the pond after remediation. There still existed a requirement to ditch additional ponds, some in areas that will have to be restored after treatment. To minimize the impact of ditching on the ecosystem and to facilitate the reconstruction of any ponds treated in this manner in the future, a lower-impact method of ditching had to be utilized.

In 2001, the draining of Pond 285 on Racine Island was scheduled. To accomplish this, Bangalore torpedoes (M1A2) were used instead of shaped and 


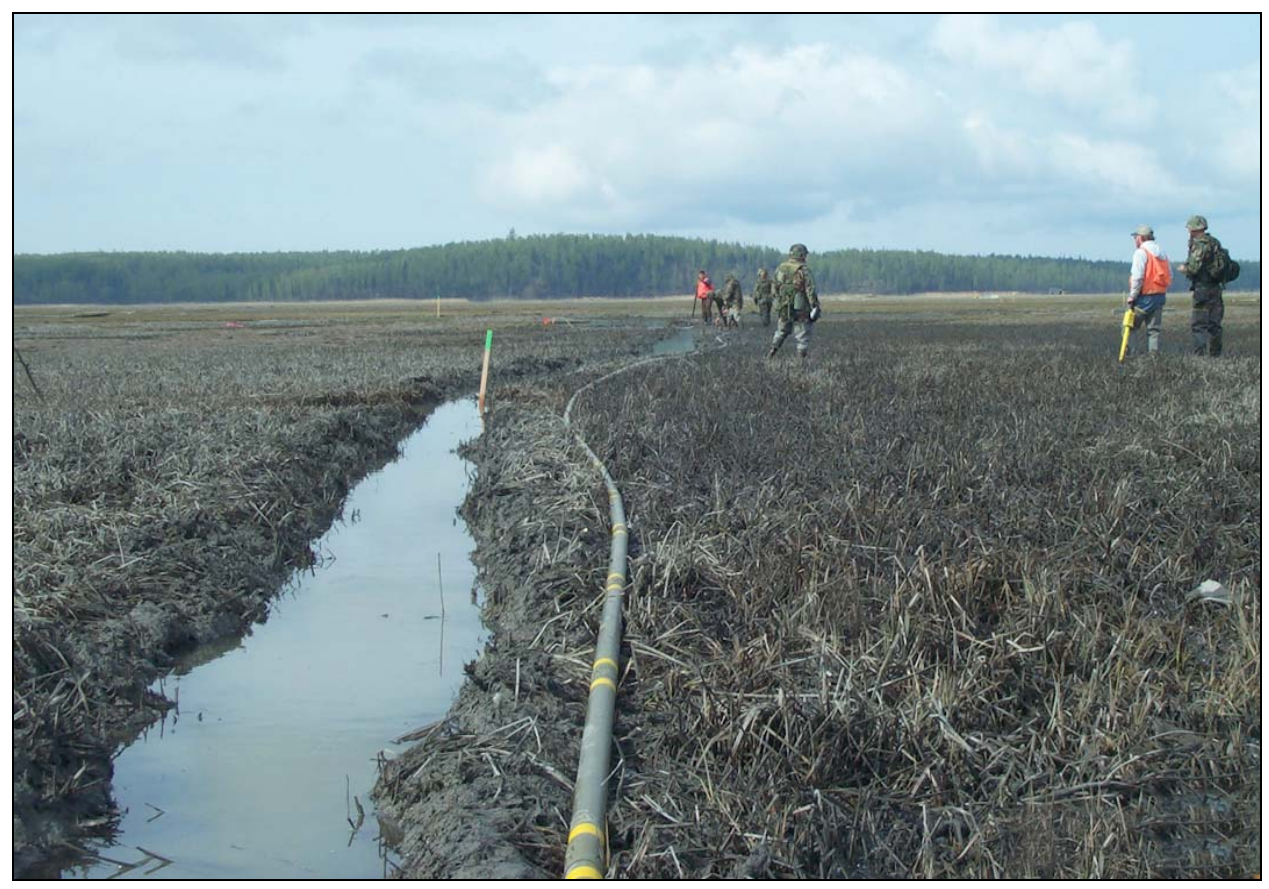

Figure 7. Laying out Bangalore torpedoes.

cratering charges to lessen the impact. Bangalore torpedoes are cylindrical demolition charges $1.52 \mathrm{~m}$ in length and $54 \mathrm{~mm}$ in diameter. The primary explosive component is Comp B4 (4.76 kg), with a 0.46-kg Comp A3 booster (U.S. Army 1998). The M1A2 Bangalore kit consists of 10 sections of torpedoes that can be assembled end-to-end using supplied sleeves to create a line charge. Any number of Bangalores can be assembled in this manner. The line charges used for ditching Pond 285 were initiated using M45 Type 1 detonation cord, a time fuse, and blasting caps placed in the detonator well of the Bangalore. Tests conducted in terrain in the Flats similar to that to be encountered between Pond 285 and the south channel of the Eagle River indicated that Bangalores placed on or cut slightly into the unfrozen surface of the sedge meadow characteristic of this area will create a ditch approximately $1 \mathrm{~m}$ wide by $70 \mathrm{~cm}$ deep.

To form the ditch to drain Pond 285, a 46-m-long string of Bangalore torpedoes was laid from the edge of the central area of the pond, across the higher vegetated levee area, to the right channel of the Eagle River (Fig. 7). The final 4 $\mathrm{m}$ of Bangalores was cut $15-20 \mathrm{~cm}$ into the levee to deepen the ditch. At the pond end, two sections of five-stranded Type-1 detonation cord were used to branch into the two arms of the pond. The detonation of the Bangalores formed a ditch approximately $55 \mathrm{~cm}$ deep by $1 \mathrm{~m}$ wide (Fig. 8). Water drained into the ditch after breaking down the ejecta rim at the pond end, but it was evident that 


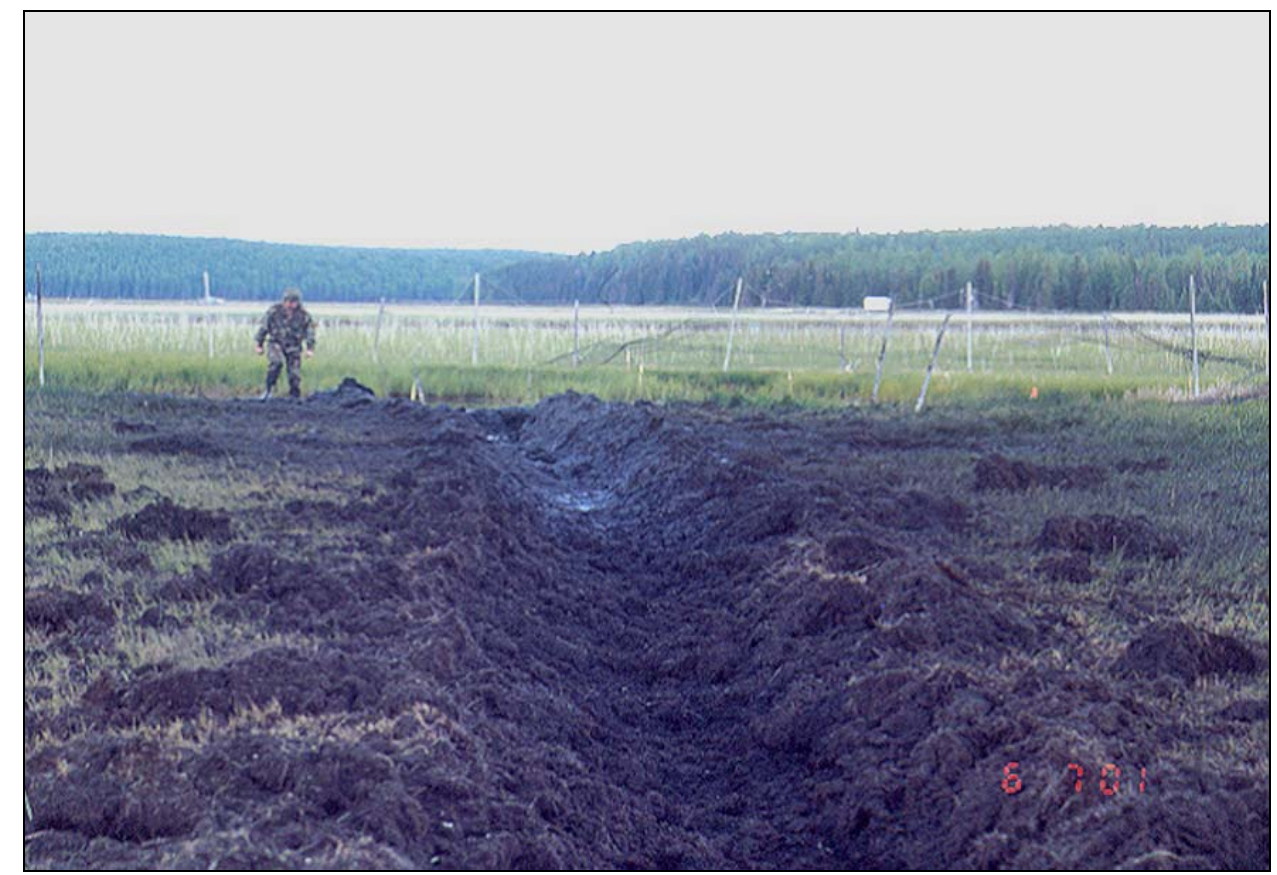

Figure 8. Drainage ditch at Pond 285 (Bangalores).

because of the higher ground of the levee next to the river, the river end of the ditch was not deep enough to allow effective drainage. An additional 12 sections of Bangalores $(18 \mathrm{~m})$ were used at the river end to further lower this end of the ditch for drainage into the river. The ditch is large enough to effectively drain the pond yet small enough to allow easy restoration of the pond if necessary.

\section{Temporary Pond Draining}

At Eagle River Flats, demolitions support for the pond-pumping remediation project during a given season typically involves multiple missions. In the spring, prior to complete thawing of the soil, or in the fall, after the equipment has been pulled, sumps are blown for the pumps and the rims of the sumps breached using Bangalore torpedoes. About a month after the pumps are deployed, when the ponds have drained to the extent possible, ditching lanes are marked for drainage from low points to the sump. The engineers then return to blast the drainage ditches to the sumps. At this time, if there is any other demolition that needs to be done, it is scheduled on top of this mission or for a later date. In all blasting missions, a helicopter must be on site for casualty evacuation in case of an accident. Some means of fire suppression is also necessary in case the demolitions spark a brush fire. Figure 9 shows the locations of sumps created for the project between 1997 and 2002. 


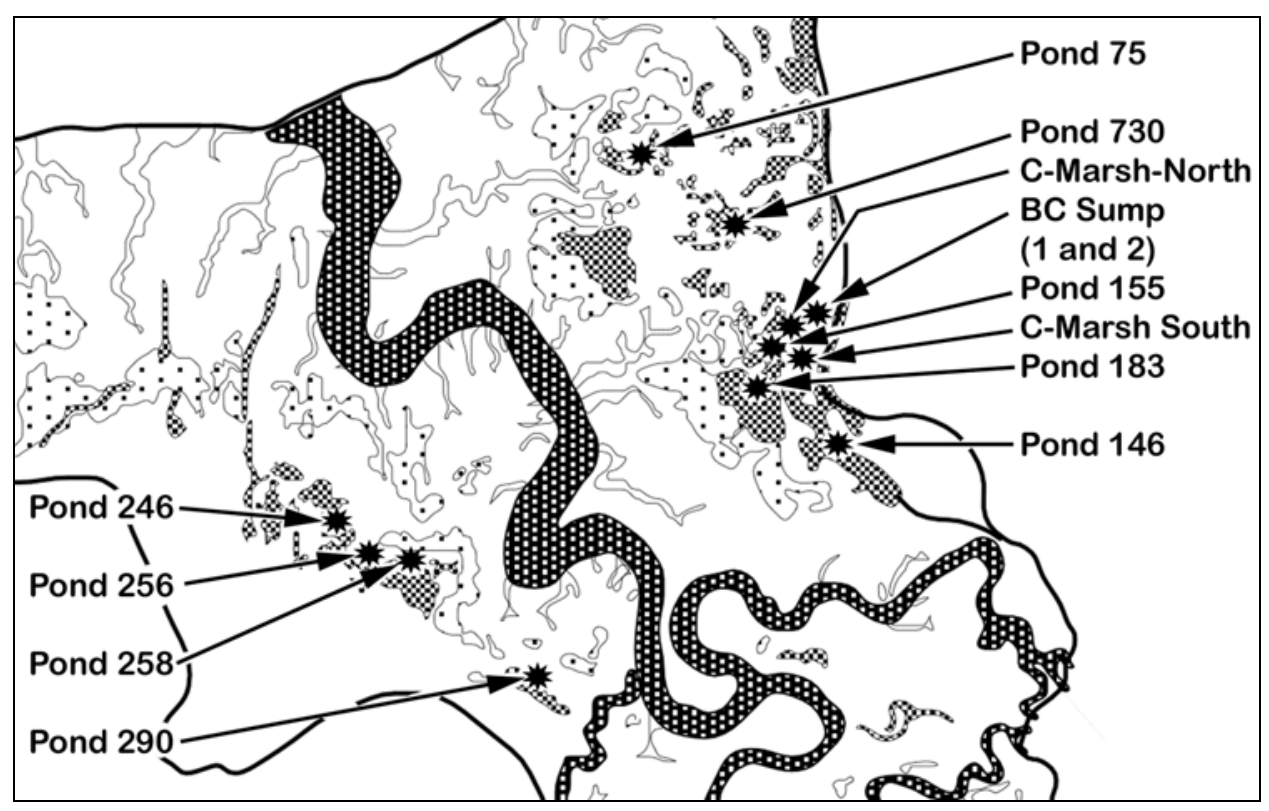

Figure 9. Location of sumps for pond-draining missions.

\section{Sump Formation in Support of Pond Pumping}

In 1997, the first pump system was deployed at Eagle River Flats in Pond 183, Area C (Walsh et al. 1999a). To operate most efficiently, a sump was required for the pump. Based on the previous blasting of the drainage ditches in Ponds 109 and 293 using multiple shaped and cratering charges, it appeared that using this method would also be effective in forming a sump. Given the general size and capacity of the pumps to be deployed at the Flats $(2.4-\times 3.7-\mathrm{m}$ plan, 126 $\mathrm{L} / \mathrm{s}$ ), the sump needs to be approximately $2 \mathrm{~m}$ deep and $8 \mathrm{~m}$ in diameter to accommodate the pump with enough area and volume to prevent excessive cycling. The minimum number of charges to achieve this was determined to be two. Setup of the charges was the same as for the ditching operation, with shaped charges on standoffs detonated first and cratering charges tamped with two sandbags each detonated in the holes formed by the shaped charges. The first sump blown was $2.5 \mathrm{~m}$ deep and $8 \mathrm{~m}$ in diameter, satisfying the requirements.

The formation of subsequent sumps since 1997 has been augmented by breaching of the crater walls around the sumps with Bangalore torpedoes. Two 1.5-m sections of torpedoes are dug in at two to four locations along the rim of the sump and detonated using a ring main line. This is very effective for breaching the crater rim around the sump and also adds to the storage volume of the sump. In areas where a small rim must be breached, a block of $\mathrm{C} 4$ has been used. 
Larger sumps have been required for the larger pump units deployed at the Flats $(190 \mathrm{~L} / \mathrm{s})$. Up to eight sets of charges have been used to blast or reblast sumps. Reblasting is necessary as the walls slough over time because of the rise and fall of the water level within the sumps. Reblasting is difficult because of the soft bottom sediments and high water level $(>1 \mathrm{~m})$ in the sumps when the work needs to be done. In some cases, the sumps have been offset for reblasting, essentially forming a new sump contiguous to the old sump. Normally, sets of two charges are used to deepen the sump. In high-flow areas where frequent cycling of the pump consumes excessive quantities of fuel, sumps have been blasted or reblasted using sets of four charges. This increases the volume of the sump and decreases the cycling frequency.

Over the course of the project (1997-2003), 13 sumps have been explosively formed at ERF (Table 4). Of these, four have been reblasted to deepen them further or counteract the effect of slumping walls. Four sumps have been formed using sets of four shaped and cratering charges and three have been formed using four shaped and eight cratering charges. Six sumps have been abandoned, as the

Table 4. Sumps blown at ERF.

\begin{tabular}{|c|c|c|c|c|c|c|c|}
\hline Pond & Area & $\begin{array}{c}\text { Pump } \\
\text { (L/s) }\end{array}$ & Blown & Charges* & Reblown & Charges* & Abandoned \\
\hline 183 & $C$ & 126 & 1997 & $2+2+0$ & 1999 & $2+2$ & 2001 \\
\hline 146 & C & 189 & 1999 & $4+4+4$ & 1999 & $4+4+4$ & \\
\hline 155 & C & 63 & 1997 & $2+2$ & & & \\
\hline 290 & A & 126 & 1997 & $2+2$ & & & 1998 \\
\hline 256 & A & 126 & 1998 & $2+2$ & & & 2000 \\
\hline 258 & A & 126 & 1998 & $2+2$ & & & 2000 \\
\hline 730 & $C / D$ & 126 & 1999 & $2+2+2$ & $\begin{array}{l}1999 \\
2001\end{array}$ & $\begin{array}{l}2+2+2 \\
4+4+4\end{array}$ & \\
\hline 75 & Coastal E & 126 & 2001 & $4+4+4$ & & & 2002 \\
\hline 246 & A & 126 & 2001 & $4+4+4$ & & & 2002 \\
\hline $\mathrm{BC}(1 \& 2)$ & C & 126 & 2002 & $8+8+10$ & $2002^{* *}$ & $4+8+10$ & \\
\hline $\begin{array}{l}\text { C-Marsh } \\
\text { (North) }\end{array}$ & C & 126 & 2002 & $4+8+4$ & & & \\
\hline $\begin{array}{l}\text { C-Marsh } \\
\text { (South) }\end{array}$ & C & 126 & 2002 & $4+8+4$ & & & \\
\hline
\end{tabular}

* Number of shape charges + cratering charges + Bangalore torpedoes

${ }^{* *}$ Original sump abandoned - Insufficient depth. 
ponds they addressed have been fully remediated and one unsuccessful sump was never used. Freeze-thaw action on the sump rims will slowly collapse the sumps, eventually resulting in a slight depression in the pond topography.

In May 2001, a newer version of the 18-kg cratering charge was used to form the three sumps in the Flats. This version contains $\mathrm{H} 6$ as the explosive and A5 as the booster. In addition, two blocks of $\mathrm{C} 4$ are used to initiate the charge, as opposed to one with the previous version. During this exercise, one four-charge sump was blown with the old (AN) version of the cratering charge, one was blown with two charges of each type, and the third blown was blown with the newer version (H6/A5). Site observations indicate that the newer charges were much more effective in the formation of the sumps than the old version." This was especially obvious in the sump where both types of charges were used.

Some valuable lessons have been learned over the course of the project. In March 2002, an attempt was made to blast a large sump through 60-cm surface ice. Eight shaped charges were used. None penetrated below the frozen ground underlying the surface ice when detonated. The cratering charges placed in the holes were not tamped with sandbags, and the resulting blast only spalled the surface ice and penetrated less than $40 \mathrm{~cm}$ into the ground. Incorrect placement of the cratering charges in the holes formed by the shaped charges has resulted in shallow sumps in other locations under different conditions. Care must be taken when mounting the initiator $(\mathrm{C} 4)$ on the cratering charge and lowering the charge into the hole formed by the shaped charge to ensure that the cratering charge is placed at the bottom of the hole. Finally, it is critical that the cratering charges be tamped with at least two sandbags. Four is better. Water is not an effective tamping agent. Tamping with four sandbags can effectively double the cratering effect of the charges when compared to having the charges covered only with water.

\section{Ditching for drainage to sumps}

Ditching from isolated low points within a pond or adjacent ponded areas to the sump requires the formation of small $(20-\times 30-\mathrm{cm})$ ditches. Both Bangalores and detonation (det) cord (M456) have been used successfully to form these ditches: Bangalores where high points or hardpan needs to be breached and detonation cord elsewhere (Fig. 10). The detonation cord is preassembled into fivestrand twisted bundles about $30 \mathrm{~m}$ long wrapped with ty-wraps every $3 \mathrm{~m}$ prior to field placement (Fig. 11). When using det cord, forcing it into the mud or precutting slots into vegetated areas and inserting the det cord into the slots greatly

* Personal communication with CPT M.H. Kelliher, 2003, following review of report on the use and effectiveness of $\mathrm{H} 6$ cratering charges versus AN cratering charges (M-039) 


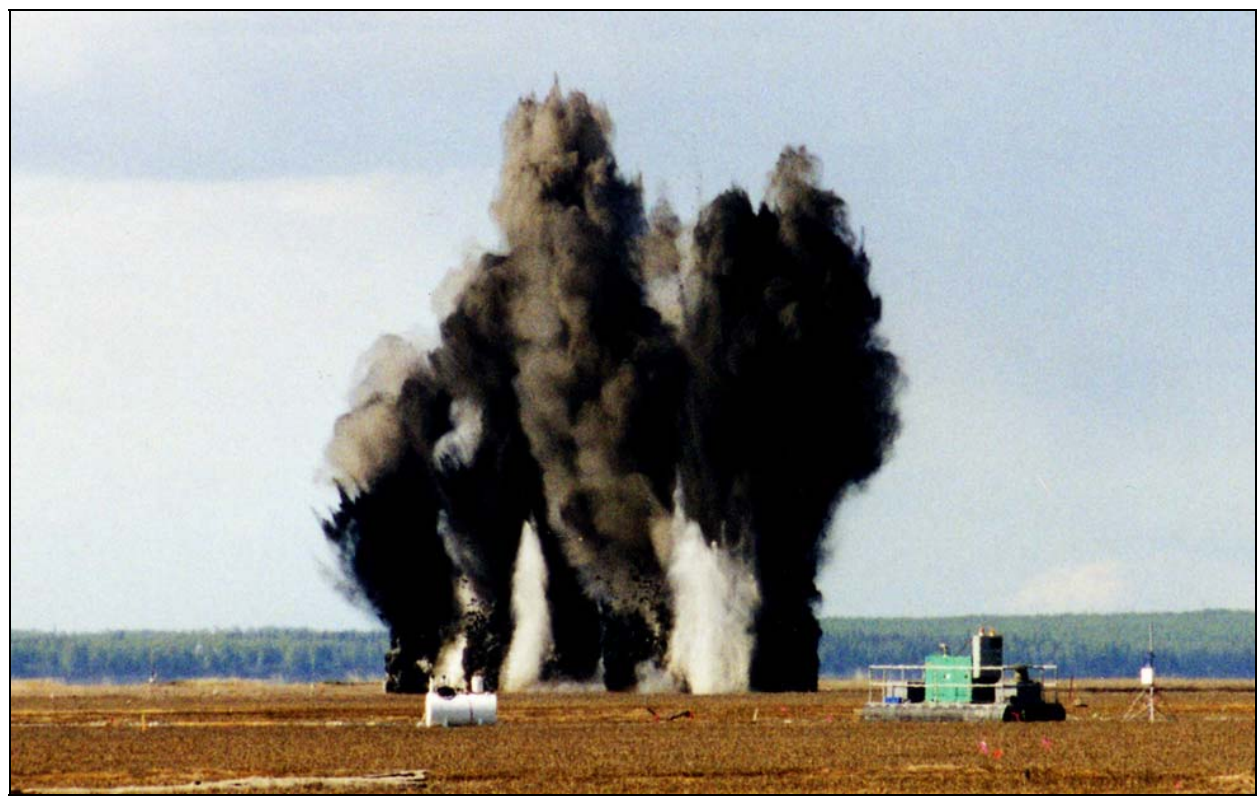

Figure 10. Blasting a sump drainage ditch with Bangalore torpedoes and det cord.

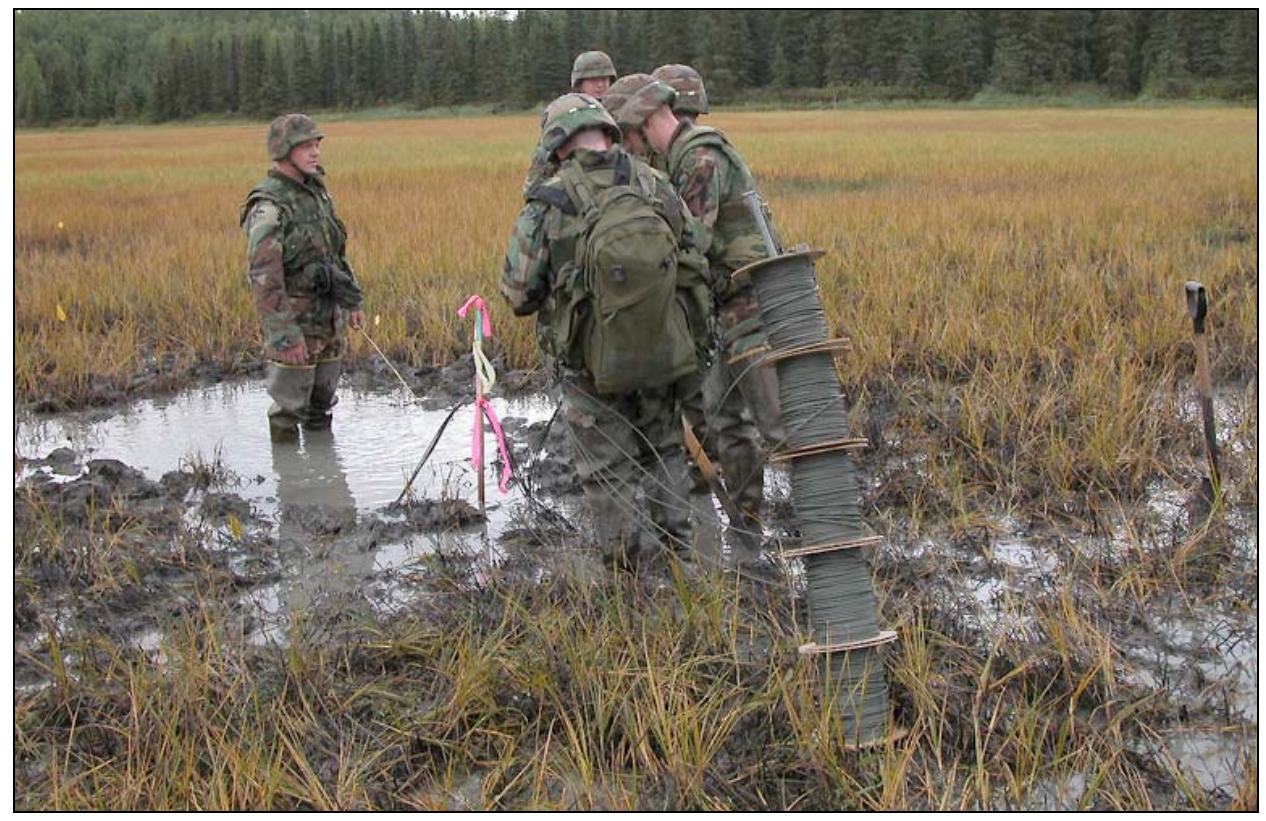

Figure 11. Field assembly of a five-strand det cord run. 
enhances its effectiveness. Recently, we have found that doubling up the detonation cord (10-strand) and inserting it in precut slots in the areas where previously only Bangalores would work, such as heavily vegetated areas will form a sufficient drainage ditch. This allows ditching through difficult materials to be conducted closer to sensitive equipment without the concussion caused by the much larger Bangalores. Ditching to sumps is now done almost exclusively with det cord.

Prior to ditching, the path of the ditch is swept for UXO and marked with lath. The path is prepared if necessary by cutting into the soil and forming a groove for placing the cord. The det cord is then laid out, tied together for lengths greater than $30 \mathrm{~m}$, and tamped into the groove or mud. A dual system of fuse igniters, time fuse, and blasting caps initiates the det cord.

Ditching with det cord is most effective shortly after an area has been drained by the pump. This allows the low points and most effective drainage path to be easily detected. The sediments are also soft enough to allow insertion and tamping of the det cord into the mud, maximizing its effect.

It is important that the det cord be pre-bundled. Bundling in the field has resulted in inconsistencies in the number of strands used (one to six) as well as long set-up times. Twisting of the det cord is also crucial to ensure that the bundle stays intact when pressed into the ground. Separation of the strands results in ineffectual excavation of the ditch. Ty-wraps alone are not sufficient, as the strands will separate when tamped. Although tamping by foot is not recommended in FM 5-250, we have not had problems with misfires due to internal cracking of the cord. This may be due to the multistrand make-up of the line.

\section{Ditching for surface water control}

In 2001, composite sampling in the field revealed that a large area of marsh at Eagle River Flats was contaminated with particulate white phosphorus. This area contained no sizeable pond to place a pump. It is also contiguous to an adjacent marsh area that is not contaminated. To isolate the contaminated area and facilitate removal of the surface water down to treatment depth $(50 \mathrm{~cm})$, a series of ditches were blasted using Bangalore torpedoes.

Although the mission occurred in late May following a record heat wave, the marsh was frozen $20 \mathrm{~cm}$ below the thawed surface. This allowed the burial of most of the Bangalores deep enough to create a ditch about $1 \mathrm{~m}$ deep in most places. In areas where the Bangalore was laid on the surface, the ditches were wider but only $0.5 \mathrm{~m}$ deep (Fig. 12). Tamping the torpedoes into the unfrozen marsh material greatly enhanced the effect of the charge and allowed much 
deeper penetration into the frozen material beneath the thaw layer of the marsh. For comparison, a Bangalore laid on the surface ice in March penetrated less than $10 \mathrm{~cm}$ when detonated (Table 5).

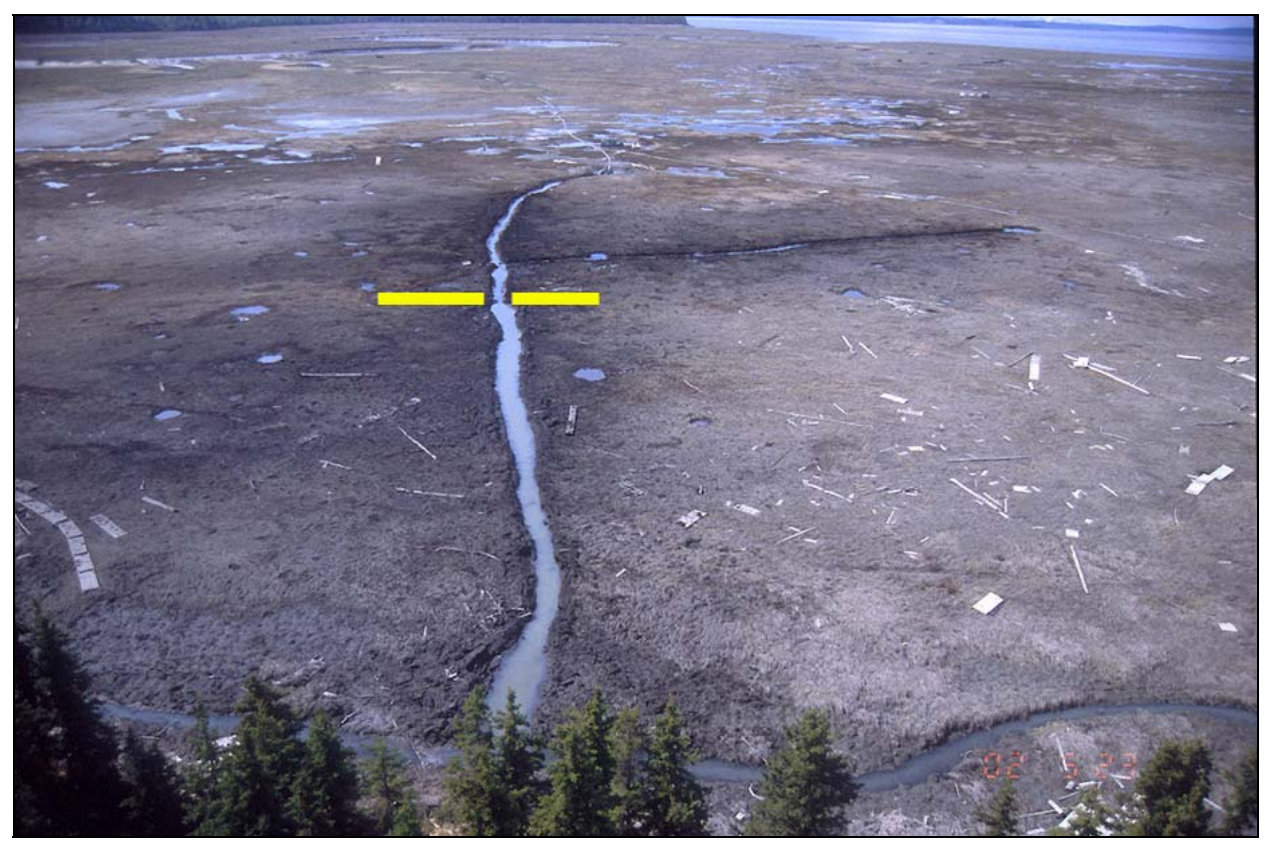

Figure 12. Bangalore ditch in Area $C$ marsh. Above the line, the charges were not cut. 
Table 5. Results of various ditching methods at ERF.

\begin{tabular}{|c|c|c|c|c|c|}
\hline Date & Munition & $\begin{array}{l}\text { Depth } \\
\text { (cm) }\end{array}$ & $\begin{array}{l}\text { Width } \\
\text { (cm) }\end{array}$ & $\begin{array}{l}\text { Ground } \\
\text { condition }\end{array}$ & Notes \\
\hline April 1996 & Cratering & 200 & 490 & Frozen soil & $\begin{array}{l}\text { 5-m spacing. } \\
1-3 \text { sandbags/hole. }\end{array}$ \\
\hline April 1997 & Cratering & 200 & 485 & Frozen soil & $\begin{array}{l}\text { 3.5-m spacing. } \\
4-5 \text { sandbags/hole }\end{array}$ \\
\hline June 1998 & Det Cord & 5 & 20 & $\begin{array}{l}\text { Submerged } \\
\text { mud }\end{array}$ & $\begin{array}{l}\text { 1-3 unstranded det } \\
\text { cord. Tamped.* }\end{array}$ \\
\hline June 2001 & Det Cord & 55 & 80 & Wet turf & $\begin{array}{l}\text { 10-strand bundle. } \\
\text { Cut into turf.* }\end{array}$ \\
\hline June 2001 & Det Cord & 10 & 30 & Hardpan & $\begin{array}{l}\text { 5-strand bundle. } \\
\text { Cut into soil. }\end{array}$ \\
\hline \multirow[t]{3}{*}{ May 2002} & Det Cord & 20 & 70 & Wet mud & $\begin{array}{l}\text { 5-strand bundle. } \\
\text { Tamped into mud. }\end{array}$ \\
\hline & Det Cord & 40 & 70 & Turf & $\begin{array}{l}\text { 5-strand bundle. } \\
\text { Cut into turf. }\end{array}$ \\
\hline & Det Cord & 10 & 30 & Wet mud & $\begin{array}{l}\text { 5-strand bundle. } \\
\text { Set on top of mud. }\end{array}$ \\
\hline June 2001 & Bangalores & 55 & 100 & $\begin{array}{l}\text { Dry thawed } \\
\text { turf }\end{array}$ & $\begin{array}{l}46-m \text {-long string. } \\
\text { Partially cut in. }\end{array}$ \\
\hline March 2002 & Bangalore & 7 & 50 & Thick ice & $\begin{array}{l}\text { Set on surface. } \\
\text { No packing. }\end{array}$ \\
\hline \multirow[t]{2}{*}{ May 2002} & Bangalores & 85 & 190 & $\begin{array}{l}\text { Subsurface } \\
\text { ice }\end{array}$ & $\begin{array}{l}\text { Cut into marsh. } \\
\text { Surface water. }\end{array}$ \\
\hline & Bangalores & 50 & 205 & $\begin{array}{l}\text { Subsurface } \\
\text { ice }\end{array}$ & $\begin{array}{l}\text { Set in marsh. } \\
\text { No tamping. }\end{array}$ \\
\hline
\end{tabular}

* Tamping done by foot to depth of approximately $5 \mathrm{~cm}$. Cut depths in ground are $20 \mathrm{~cm}$. 


\section{EVALUATION}

The use of military explosives has proven to be a very effective means of surface water control at Eagle River Flats. The exposure of field personnel to $\mathrm{UXO}$ is greatly reduced when lanes in the mission areas are cleared beforehand with a magnetometer. Post-detonation sweeping of the area for UXO is required after all detonations.

Planning is critical to the successful completion of the blasting missions. Areas to be addressed must be marked and cleared prior to the mission to ensure that the correct areas are addressed in a safe manner. This also aids in planning the amount of demolitions that will be required for the mission. Demolitions for large missions should be drawn the day prior to deployment. Preparation of the demolitions, - cutting and bundling the det cord, preparing the shape charges, readying sand bags, and sorting the demolitions by mission segment - and predeployment of the materiel can be done prior to arrival of the helicopter. With the helicopter on site, multiple sites can be prepared prior to blasting of the first site. In all operations, though, care must be taken to ensure that all safety procedures are followed.

Using the right materiel for the mission is also important. The use of cratering charges to blast ditches to drain ponds proved to be overkill. The use of Bangalores is a much less intrusive method to accomplish this task, but blasting must occur when the surface is thawed to be able to cut the ordnance into the soil and obtain the desired depth of penetration. It is also much easier to restore the smaller ditch formed by the Bangalore than it is to restore the very large ditch formed by cratering charges. Conversely, the use of Bangalores for forming drainage ditches to sumps has been generally superceded by using multiple strands of detonation cord twisted and wrapped into a bundle and inserted into the soil. The use of higher-strength commercial detonation cord would simplify this operation greatly. 


\section{CONCLUSIONS}

Demolitions support at Eagle River Flats is critical to the execution of the remediation mission at this Superfund site. The ability to excavate large sumps, drain untreatable areas, and control surface water have all contributed to the success of this project. In addition, the use of explosives rather than manual or mechanical excavation has reduced the exposure of personnel to unexploded ordnance, the greatest safety hazard on the project site. The techniques developed and experience gained in surface water management over the course of this project can be readily transferred to other areas and applications, both military and civilian. 


\section{REFERENCES}

Collins, C.M., E.R. Chacho, M.R. Walsh, and M.E. Walsh (1996) Pond draining treatability: 1995 studies. In Interagency Expanded Site Investigation: Evaluation of White Phosphorus Contamination and Potential Treatability at Eagle River Flats, Alaska: FY95 Final Report (C.H. Racine and D. Cate, ed.). Contract Report to U.S. Army, Alaska, Directorate of Public Works. Cold Regions Research and Engineering Laboratory, Hanover, New Hampshire, p. 267-309.

Lawson, D.E., S.R. Bigl, and J.H. Bodette (1994) Physical system dynamics. In Interagency Expanded Site Investigation: Evaluation of White Phosphorus Contamination and Potential Treatability at Eagle River Flats, Alaska: FY93 Final Report (C.H. Racine and D. Cate, ed.). Contract Report to U.S. Army Garrison, Alaska, Directorate of Public Works. Cold Regions Research and Engineering Laboratory, Hanover, New Hampshire, p. 25-83.

Lawson, D.E., S.R. Bigl, and J.H. Bodette (1995) Physical system dynamics, WP fate and transport, remediation and restoration. In Interagency Expanded Site Investigation: Evaluation of White Phosphorus Contamination and Potential Treatability at Eagle River Flats, Alaska: FY94 Final Report (C.H. Racine and D. Cate, ed.). Contract Report to U.S. Army, Alaska, Directorate of Public Works. Cold Regions Research and Engineering Laboratory, Hanover, New Hampshire, vol. 1, p. 53-186.

Lawson, D.E., L.E. Hunter, and S.R. Bigl (1996) Physical system dynamics, WP fate and transport, and remediation. In Interagency Expanded Site Investigation: Evaluation of White Phosphorus Contamination and Potential Treatability at Eagle River Flats, Alaska: FY95 Final Report (C.H. Racine and D. Cate, ed.). Contract Report to U.S. Army, Alaska, Directorate of Public Works. Cold Regions Research and Engineering Laboratory, Hanover, New Hampshire, p. 21112.

Livingston, C.W. (1956) Excavations in frozen ground. Part I: Explosion tests in Keweenaw silt. Technical Report 30, U.S. Army Snow, Ice and Permafrost Research Establishment.

Livingston, C.W. (1959) Excavations in frozen ground. Part II: Explosion tests in frozen glacial till, Fort Churchill. Technical Report 30, U.S. Army Snow, Ice and Permafrost Research Establishment.

Livingston, C.W. (1960) Explosions in ice. Technical Report 75, U.S. Army Snow, Ice and Permafrost Research Establishment. 
Mellor, M. (1965) Explosions and snow. Monograph, Part III, Section A3a, Cold Regions Research and Engineering Laboratory, Hanover, New Hampshire.

Mellor, M. (1982) Breaking ice with explosives. CRREL Report 82-40, Cold Regions Research and Engineering Laboratory, Hanover, New Hampshire.

Mellor, M. (1986a) Revised guidelines for blasting floating ice. Special Report 86-10, Cold Regions Research and Engineering Laboratory, Hanover, New Hampshire.

Mellor, M. (1986b) Blasting and blast effect in cold regions, Pt II: Underwater explosions. Special Report 86-16, Cold Regions Research and Engineering Laboratory, Hanover, New Hampshire.

Mellor, M. (1989) Blasting and blast effects in cold regions. Part 3: Explosions in ground materials. Special Report 89-15, Cold Regions Research and Engineering Laboratory, Hanover, New Hampshire.

Mellor, M., and P.V. Sellmann (1970) Experimental blasting in frozen ground. Special Report 153, Cold Regions Research and Engineering Laboratory, Hanover, New Hampshire.

Racine, C.H., M.E. Walsh, C.M. Collins, D.J. Calkins, and B.D. Roebuck (1991) Waterfowl mortality in Eagle River Flats, Alaska: The role of munition compounds. Contract Report to U.S. Army Toxic and Hazardous Materials Agency, Aberdeen Proving Ground, Maryland. USATHAMA Report No. CETHA-IR-CR-991008. Cold Regions Research and Engineering Laboratory, Hanover, New Hampshire.

Racine, C.H., M.E. Walsh, B.D. Roebuck, C.M. Collins, D.J. Calkins, L. Reitsma, P.J. Baluchi, and G. Goldfarb (1992) White phosphorus poisoning of waterfowl in an Alaskan salt marsh. Journal of Wildlife Diseases, 28(4): 669673.

Racine, C.H., M.E. Walsh, C.M. Collins, S. Taylor, B.D. Roebuck, L. Reitsma, and B. Steele (1993) White phosphorus contamination of salt marsh sediments at Eagle River Flats, Alaska. CRREL Report 93-17, Cold Regions Research and Engineering Laboratory, Hanover, New Hampshire.

Roebuck, B.D., S.I. Nam, D.L. Macmillan, K.J. Baumgartner, and M.E. Walsh (1998) Toxicology of white phosphorus to ducks and risk for their predators: Effects of particle size. Environmental Toxicology and Chemistry, 17:(3) 511-518.

Smith, N. (1982) Testing shaped charges in unfrozen and frozen silt in Alaska. Special Report 82-2, Cold Regions Research and Engineering Laboratory, Hanover, New Hampshire. 
Steele, B.B, L.R. Reitsma, C.H. Racine, S.L. Burson, R. Stuart, and R.

Theberge (1997) Different susceptibilities to white phosphorus poisoning among five species of ducks. Environmental Toxicology and Chemistry, 16(11): 22752282.

Tweten, R. (1989) Eagle River Flats waterfowl mortality investigation progress report. U.S. Fish and Wildlife Service, Tudor Road, Anchorage, Alaska (Unpublished).

U.S. Army (1987) Engineer Field Data. Field Manual FM5-34.

U.S. Army (1998) Explosives and Demolitions. Field Manual FM5-250.

Walsh, M.E., C.M. Collins, and C.R. Racine (1995) Factors that determine the persistence of white phosphorus particles in sediment. CRREL Report 95-23, Cold Regions Research and Engineering Laboratory, Hanover, New Hampshire.

Walsh, M.E., C.M. Collins, and C.R. Racine (1996) Persistence of white phosphorus (P4) particles in salt marsh sediments. Environmental Toxicology and Chemistry, 15(6): 846-855.

Walsh, M.R., M.E. Walsh, and C.M. Collins (1999a) Enhanced natural remediation of white-phosphorus-contaminated wetlands through controlled pond draining. CRREL Report 99-10, Cold Regions Research and Engineering Laboratory, Hanover, New Hampshire.

Walsh, M.R., M.E. Walsh, and C.M. Collins (1999b) Remediation methods for white-phosphorus contamination in a coastal salt marsh. Environmental Conservation, 26(2): 112-124.

Walsh, M.R., M.E. Walsh, and C.M. Collins (2000) Methods for attenuation of white phosphorus contamination in wetlands. Journal of Environmental Engineering, 126(11): 1013-1018. 